\title{
EFFECTIVENESS OF INDIGENOUS ENDOMYCORRHIZAL BIOFERTILIZER PROTOTYPE ON ORGANIC SALAK LEAVES AND FRUITS IN BALI
}

\author{
I NYOMAN RAI ${ }^{1 *}$, I KETUT SUADA ${ }^{1}$, I WAYAN WIRAATMAJA AND \\ NI KOMANG ALIT ASTIARI² \\ 'Study Program of Agroecotechnology, Faculty of Agriculture, Universitas Udayana, Kampus Unud, Bukit Jimbaran, Kuta Selatan, \\ Badung 80361, Bali, Indonesia \\ ${ }^{2}$ Study Program of Agrotechnology, Faculty of Agriculture, Universitas W armadewa, Denpasar 80235, Bali, Indonesia
}

Received 14 February 2020 / Accepted 1 July 2020

\begin{abstract}
Organically cultivated salak (Salacca zalacca) on dry land has limited production in Bali. Typically, fertilization is carried out using leaf litter or other organic fertilizers because soil fertility is low for salak plantations. The present study analyzed the effectiveness of an indigenous endomycorrhizal biofertilizer on the nutrient and total carbohydrate content of salak leaves and fruits. The study used a randomized block design with nine replicates. The treatment consisted of three levels, i.e., 1. fertilization with leaf litter only, as is practiced by the farmers and as control $(\mathrm{C}) ; 2$. fertilization with indigenous endomycorrhizae biofertilizer prototype $(\mathrm{P})$; and 3. combined fertilization with leaf litter and indigenous endomycorrhizae biofertilizer prototype (PM). Spores of indigenous endomycorrhizae from salak plantations were used for making a biofertilizer prototype. The results showed that $\mathrm{P}$ and $\mathrm{CP}$ treatments provided beneficial results such as: 1 . significantly increased the chlorophyll, relative water content of leaves, as well as the number and weight of fruits per tree; 2 . improved fruit quality by increasing sweetness and weight per fruit; and 3. had a positive effect on water uptake and nutrient absorption as indicated by high $\mathrm{N}$ and $\mathrm{P}$ of leaf tissue and high carbohydrate content of leaves.
\end{abstract}

Keywords: biofertilizer, endomycorrhizae, organic, prototype, Salacca zalacca

\section{INTRODUCTION}

Bali Province is a major tourist destination in Indonesia. Increasing the number of domestic and international tourists leads to an increased demand for fruits, including organic salak fruits. Salak cultivation in Bali has been carried out organically since the $1500 \mathrm{~s}$ and is hugely beneficial to the farmers; however, the quantity, quality, and continuity of organic salak fruit produced is low (Rai et al. 2014).

This low productivity can be attributed to the nature-dependency of the farmers, who have not yet implemented adequate agricultural practices. Typically, fertilization only uses leaf litter, while irrigation relies only on rainfall. Thus, the fertilization of organic salak renders low soil fertility thereby decreasing the plant productivity

Corresponding author, email: rainyoman@unud.ac.id over time (Rai et al. 2014). Rai et al. (2010) found that the nutrient content of $\mathrm{N}, \mathrm{P}$, and $\mathrm{K}$ in the leaf tissue of organic salak in Bali was low; also, the soil fertility was low as indicated by the levels of C-organic and the content of N, P, and $\mathrm{K}$ in the soils. In order to maintain the soil fertility and environmental sustainability for high organic salak productivity, the cultivation should be carried out with indigenous endomycorrhizae biofertilizer based on the fact that the diversity of indigenous endomycorrhizae fungal species in nature is very large (Baslam et al. 2011; Proborini 2013; Suamba et al. 2014; Sarah \& Ibrar 2016; INVAM 2017).

Kim et al. (2017) established a close correlation between soil, plants, and endomycorrhizae. Indigenous endomycorrhizae isolated from plants in certain locations, will be more effective if applied directly to the target plant concerned where it is taken as compared 
to the endomycorrhizae brought from outside (non-indigenous endomycorrhizae). The arbuscular mycorrhizal symbiosis between plants and fungi exerts a positive impact on improving the soil structure, expanding the water absorption areas, increasing the plant tolerance to biotic and abiotic stresses, increasing the nutrient uptake, and increasing the plant growth and yield (Nikhat 2014; Olagunju et al. 2014; Soka \& Ritchie 2016). In addition, endomychorrizae increases plant tolerance to various biotic and abiotic stresses, including alkalinity and metal toxicity (Abbasi et al. 2015; Bitterlich et al. 2018). The endomycorrhizae fungus which is also called arbuscular mycorrhizae is beneficial to the host plants as it plays a role in increasing nutrient absorption through the endomycorrhizal structures that form large root surface areas so that the plant roots can absorb the nutrients (Baslam et al. 2011; Sasvari 2012; Brundrett \& Tedersoo 2018). Endomycorrhizae plays a role in increasing plant resistance to root pathogen attack through antibiotics produced during symbiosis with plant roots that weaken and also kill the pathogenic bacteria, viruses, and fungi (Brundrett 2017; Sasvari, 2012).

Furthermore, the diversity and activity of indigenous endomycorrhizae in plant roots are mainly determined by the type of the host plant (Ningsih et al. 2013; Sadhana 2014), environmental growth factors, such as climate and soil moisture/drought (Hernadi 2012; Quiroga et al. 2017; Mathimaran et al. 2017; Kehri et al. 2018), and the level of soil fertility (Tahat \& Sijam 2012; Kavitha \& Nelson 2013; Mo et al. 2016). Rai et al. (2019a) explored and identified morphologically and genetically the indigenous endomycorrhizae from salak root areas in three regencies in Bali: Karangasem, Gianyar, and Tabanan. In our study, two genera of indigenous endomycorrhizae in salak were identified i.e., Glomus and Entrophospora. The genus Glomus consisted of three species (Glomus cubens, Glomus custos, and Glomus indicum), while genus Entrophospora consisted of only one species (Entrophospora_sp_SH197095.06FU). After propagation, the spores of these species were formulated into prototypes of biological fertilizers/biofertilizer with carrier media zeolite, quartz sand, sea sand, and volcanic sand. The most effective method to be applied in salak seedling is a prototype composed of a mixture of 100 spores from Glomus species in $500 \mathrm{~g}$ volcanic sand carrier media. This phenomenon was shown by the optimal growth of salak seedling and the maximum $(100 \%)$ colonization of endomycorrhizae at the roots (Rai et al, 2019b). Positive test results on salak seedling growth need to be followed up by evaluating the efficiency of the prototype of indigenous endomycorrhizae biofertilizer on organic salak plantations in the field. Thus, the present study aimed to determine the effect of prototype indigenous endomycorrhizae biofertilizers on organic salak production and its effect on the nutrient and carbohydrate content of the leaves.

\section{MATERIALS AND METHODS}

The study was conducted from February to December 2019 in organic salak farms owned by farmers in Sibetan Village, Bebandem District, Karangasem Regency. The study used 15-yearold salak trees and a randomized block design with nine replicates. Three levels of fertilization were applied as follows: 1. fertilized with leaf litter only, as is practiced by the farmers and as control (C); 2. fertilized with prototype indigenous endomycorrhizae biofertilizer $(\mathrm{P})$; and 3. combination of leaf litter and prototype indigenous endomycorrhizae biofertilizer (CP). Therefore, 27 salak trees with a total plot size of $216 \mathrm{~m}$ square were needed.

The spores of indigenous endomycorrhizae were taken from salak roots in Sibetan Village. The isolation of the spores was carried out using the wet filtering technique, followed by centrifugation as described by Brundrett (2017). These spores were propagated according to the method described by Rai et al. (2018), using corn as a host plant with water stress treatments. Topping or shoot cutting was carried out at the age of 4 weeks. Watering to field capacity was carried out from the beginning of seed planting to 1 week of age, followed by watering to $50 \%$ of field capacity until 4 weeks of age. After topping at the end of the $4^{\text {th }}$ week, watering was stopped so that the plant experienced stress. Then, the plant was dismantled to harvest the spores from the multiplication at the end of the $5^{\text {th }}$ week. Subsequently, the resulting spores were placed on volcanic sand: 100 spores $/ 500 \mathrm{~g}$ sand. 
Fertilization was conducted by making a hole, $30 \mathrm{~cm}$ wide and $20 \mathrm{~cm}$ deep, around the tree at a distance of $40 \mathrm{~cm}$ from the base of the tree. The salak trees in treatment $C$ were fertilized with 4 $\mathrm{kg}$ leaf litter of salak/tree. The leaves were cut into 20 -cm-long pieces, placed in a hole, and covered with soil. On the other hand, the trees in the $\mathrm{P}$ treatment were fertilized with prototype indigenous endomycorrhizae made from a mixture of 100 spores of three Glomus species (Glomus cubense, Glomus Custos, and Glomus indicum) in $500 \mathrm{~g}$ volcanic sand carrier media per plant. The prototype of the biofertilizer was evenly spread around the tree and covered with soil. Interestingly, the $\mathrm{CP}$ treatment was carried out by spreading a prototype of the biofertilizer made from a mixture of 100 spores of three Glomus species in $500 \mathrm{~g}$ of volcanic sand carrier media per plant, followed by spreading the salak leaf litter on it evenly around the tree.

The chlorophyll content and the relative water content (RWC) of the leaves, the percentage of fruit set, the number and weight of fruits per tree, weight per fruit, fruit diameter, fruit sweetness level, $\mathrm{N}$ and $\mathrm{P}$ content of the leaves, and total sugar, reducing sugar ( $\mathrm{R}$-sugar) and sucrose content of the leaves, and root colonization by indigenous endomycorrhizae were recorded. The colonization of roots by indigenous endomycorrhizae was observed by the slide method of Giovannetti and Mosse (1980) using the following formula: percentage of colonized roots $=$ the number of colonized roots/the total number of roots observed $\times$ $100 \%$. The percentage of fruit set was calculated as follows: the number of flowers developed into fruits/the number of flowers $\times 100 \%$. The leaf chlorophyll content measured three times by Chlorophyll Meter SPAD-502 in April, June, and August, and the average was calculated. The total sugar was analyzed by anthrone method, Rsugar by Nelson-Somogyi method, and the sucrose content was calculated by subtracting the value of total sugar content from that of Rsugar, and multiplied by 0.95 . The RWC was measured from matured leaves. After being cut from the tree, the mature leaves were then immediately wrapped in aluminium foil, stored in an icebox, and transported to the laboratory for further analysis. Thirty pieces of leaf samples (10 pieces from the tip of the leaf, 10 pieces from the middle, and 10 pieces from the bottom), with a diameter of $1 \mathrm{~cm}$, were taken from leaf sheaths using a round punch and weighed $\left(W_{1}\right)$. These leaf samples were immersed in water and irradiated with $40 \mathrm{~W}$ fluorescent light at room temperature for $5 \mathrm{~h}$. Then, each piece of leaf sample was carefully dried with paper towel, and weighed $\left(\mathrm{W}_{2}\right)$, followed by oven-drying at $70{ }^{\circ} \mathrm{C}$ for $24 \mathrm{~h}$ before being estimated $\left(\mathrm{W}_{3}\right)$. The value of RWC was calculated by the formula: $\left(\mathrm{W}_{1}-\mathrm{W}_{2}\right) /$ $\left(\mathrm{W}_{3}-\mathrm{W}_{2}\right) \times 100 \%$. The nutrient content of $\mathrm{N}$ and $\mathrm{P}$ leaves was analyzed by Kjeldahl method and the P-availability was analyzed by Olsen method. The number and weight of fruits per tree were calculated cumulatively at the end of the study. Moreover, the weight of each fruit was calculated as follows: total weight of fruit per tree/the number of fruits per tree.

These data were analyzed using analysis of variance with SPSS (Statistical Product and Service Solution) software version 26. If the F test showed a significant difference, the least significant difference (LSD) test was performed to differentiate the average value among tretaments.

\section{RESULTS AND DISCUSSION}

The results of the analysis of variance (ANOVA) showed that the fertilization treatment significantly affected all the observed variables. The weight and number of fruits per tree $(790.80 \mathrm{~g}$ and 16.81 fruits, respectively) in the treatment of indigenous endomycorrhizae biofertilizer prototype (100 spores/500 g volcanic sand carrier media) were significantly higher than those fertilized with leaf litter/control (653.81 $\mathrm{g}$ and 14.94 fruits, respectively), but were not significantly different from CP (790.14 $\mathrm{g}$ and 16.56 fruits, respectively) (Table 1). The quality of salak fruit in the $\mathrm{P}$ and $\mathrm{CP}$ treatments was significantly improved as compared to that in treatment $\mathrm{C}$, as shown by the increased sweetness of the fruit (Table 2) and the weight per fruit (Table 1). The high number and weight of fruit per tree, as well as the increased fruit quality due to the administration of indigenous endomycorrhizae biofertilizer prototype, elevated the $\mathrm{N}$ and $\mathrm{P}$ content of the leaves as compared to the control (Table 2); also, the chlorophyll content and RWC of the leaves were increased (Table 1). Visually, the trees treated with $\mathrm{C}$ and $\mathrm{CP}$ treatments had dark green and fresh leaves as compared to the control. 
Table 1 Effect of prototype indigenous endomycorrhizae biofertilizers on the leaf chlorophyll content, RWC of leaves, number and weight of fruits per tree, weight per fruit, and fruit sweetness in salak plants

\begin{tabular}{ccccccc}
\hline Treatments & $\begin{array}{c}\text { Leaves chlorophyll } \\
\text { content } \\
\text { (SPAD) }\end{array}$ & $\begin{array}{c}\text { Leaves relative } \\
\text { water content } \\
(\%)\end{array}$ & $\begin{array}{c}\text { Number of } \\
\text { fruit per tree } \\
\text { (unit) }\end{array}$ & $\begin{array}{c}\text { Weight of } \\
\text { fruit per tree } \\
(\mathrm{g})\end{array}$ & $\begin{array}{c}\text { Weight per } \\
\text { fruit } \\
(\mathrm{g})\end{array}$ & $\begin{array}{c}\text { Fruit } \\
\text { sweetness } \\
(\% \text { Brix }\end{array}$ \\
\hline $\mathrm{C}$ & $68.82 \mathrm{~b}$ & $55.03 \mathrm{~b}$ & $14.94 \mathrm{~b}$ & $653.81 \mathrm{~b}$ & $44.09 \mathrm{a}$ & $12.89 \mathrm{~b}$ \\
$\mathrm{P}$ & $76.83 \mathrm{a}$ & $65.37 \mathrm{a}$ & $16.81 \mathrm{a}$ & $790.80 \mathrm{a}$ & $47.61 \mathrm{a}$ & $13.72 \mathrm{a}$ \\
$\mathrm{CP}$ & $77.46 \mathrm{a}$ & $65.75 \mathrm{a}$ & $16.56 \mathrm{a}$ & $790.14 \mathrm{a}$ & $47.97 \mathrm{a}$ & $14.66 \mathrm{a}$ \\
\hline LSD 5\% & 0.67 & 0.98 & 1.59 & 96.34 & 7.27 & 0.51 \\
\hline
\end{tabular}

Note: Numbers followed by the same letter in the same column did not differ significantly in the LSD $5 \%$ level.

Higher production and yield quality in $\mathrm{P}$ and $\mathrm{CP}$ treatments as compared to control $(\mathrm{C})$ were related to high leaf chlorophyll content (Table 1) and the ability of salak tree to absorb nutrients and water (Table 2). The high $\mathrm{P}$ and $\mathrm{N}$ content in the leaves resulted from the $\mathrm{P}$ and $\mathrm{CP}$ treatments was significantly associated with root colonization as compared to the $\mathrm{C}$ treatment. Table 2 displayed that root colonization by indigenous endomycorrhizae in the $\mathrm{P}$ and $\mathrm{CP}$ treatments was $100 \%$, but only $23.14 \%$ in treatment $\mathrm{C}$. The high root colonization in $\mathrm{P}$ and $C P$ revealed a mutualism symbiosis between indigenous endomycorrhizae and salak trees, which in turn, increased the $\mathrm{P}$ and $\mathrm{N}$ content and the RWC in the leaves. The endomycorrhizae infects the roots of plants but does not cause injury, which in turn causing mutual reciprocal processes. Host plants obtain nutrients from endomycorrhizae, while endomycorrhizae obtain carbohydrates or food from host plants (Hernadi et al. 2012; Zasvari et al. 2012).

High nutrient content and RWC in the leaves resulted from the $\mathrm{P}$ and $\mathrm{CP}$ treatments increased the chlorophyll content, which improved the photosynthesis as indicated by elevated total sugar, R-sugar, and sucrose content in the leaves resulted from the $\mathrm{P}$ and $\mathrm{CP}$ treatments as compared to that in $\mathrm{C}$ (Table 2). The present study showed that indigenous endomycorrhizae fungus isolated from root of salak trees is suitable to be used as a biofertilizer. The administration of indigenous endomycorrhizae resulted in the absorption of nutrients and water through the endomycorrhizae structure that enlarges the surface area of salak root, so that the plant roots can absorb the nutrients and water (Baslam et al. 2011; Zasvari 2012;
Brundrett \& Tedersoo 2018, Bitterlich et al. 2018).

Spore density and root colonization of host plants are largely determined by the compatibility of endomycorrhizae with host plants, environmental factors, and interactions between endomycorrhizae and chemical compounds produced by host plants (Beltrano et al. 2013; Sarah \& Ibrar 2016). Thus, a correlation between indigenous endomycorrhizae biofertilizers prototype and salak trees can be suspected, which increases the yield, the quality of the yield, and the physiological processes of salak trees. The results of this efficiency test are in accordance with those of previous studies wherein endomycorrhizal fungi biofertilizer can increase the growth, production and quality of pineapple yield (Nurhandayani et al. 2013), chili (Tanwar et al. 2013), teak (Proborini, 2013), tea (Nepaleon et al. 2012) and apple (Fediala et al. 2018). Endomycorrhizae plays a role in increasing plant resistance to drought or lack of water in the dry season because the root of the plants possess mycelium that can reach water in the wider rhizosphere area of the soil and adsorb water despite limited availability (Sasvari 2012). Furthermore, it is involved in producing various growth regulators such as auxins, cytokinins, and gibberellins and vitamins that can increase the growth of plant organs and roots that do not rapidly age and hence can function effectively in the absorption of nutrients and other solutes (Baslam et al. 2011; Tanwar et al. 2013). The endomycorrhizae also improve the soil structure because the mycelium on the outside of the roots of plants (covering soil grains) produces polysaccharide gels that increase the stability of soil aggregates (Kruger 2011; Sasvari 2012; Sadhana 2014; Jansa et al. 2016; Kim et al. 2017). 
Table 2 Effect of prototype indigenous endomycorrhizae biofertilizer application on the $\mathrm{N}$ and $\mathrm{P}$ nutrient, total sugar, R-sugar, and sucrose content of the leaves and root colonization on salak plants

\begin{tabular}{ccccccc}
\hline Treatments & $\begin{array}{c}\text { N content } \\
\text { of leaves } \\
(\%)\end{array}$ & $\begin{array}{c}\text { P content of } \\
\text { leaves } \\
(\%)\end{array}$ & $\begin{array}{c}\text { Total sugar } \\
\text { content of } \\
\text { leaves } \\
(\%)\end{array}$ & $\begin{array}{c}\text { R-sugar } \\
\text { content of } \\
\text { leaves } \\
(\%)\end{array}$ & $\begin{array}{c}\text { Sucrose content } \\
\text { of leaves } \\
(\%)\end{array}$ & $\begin{array}{c}\text { Root } \\
\text { colonization } \\
(\%)\end{array}$ \\
\hline C & $0.50 \mathrm{a}$ & $0.23 \mathrm{~b}$ & $21.35 \mathrm{~b}$ & $1.96 \mathrm{~b}$ & $18.91 \mathrm{~b}$ & $23.14 \mathrm{~b}$ \\
$\mathrm{P}$ & $0.52 \mathrm{a}$ & $0.26 \mathrm{a}$ & $23.48 \mathrm{a}$ & $3.35 \mathrm{a}$ & $21.41 \mathrm{a}$ & $100.00 \mathrm{a}$ \\
$\mathrm{CP}$ & $0.53 \mathrm{a}$ & $0.27 \mathrm{a}$ & $24.71 \mathrm{a}$ & $3.41 \mathrm{a}$ & $21.73 \mathrm{a}$ & $100.00 \mathrm{a}$ \\
\hline LSD 5\% & 0.03 & 0.01 & 0.51 & 0.22 & 0.79 & 3.16 \\
\hline
\end{tabular}

Note: Numbers followed by the same letter in the same column did not differ significantly in the LSD $5 \%$ level.

Although $\mathrm{C}$ was not given indigenous endomycorrhizae biofertilizer, root colonization occurred albeit with significantly lower intention as compared to that in $\mathrm{P}$ and $\mathrm{CP}$ treatments. The data showed that indigenous endomycorrhizae were naturally present in salak root area; however, for a positive influence on the production and quality of salak, the population needed to be increased by giving indigenous endomycorrhizae biofertilizer for the optimal production of the plants. The indigenous endomycorrhizal fungi, also known as arbuscular mycorrhizal fungi, in nature is diversified (Baslam et al. 2011; Proborini 2013; Suamba et al. 2014), with a positive effect on the salak trees (Juliadewi et al. 2014). Indigenous endomycorrhizae is naturally associated with plant roots without human intervention and has a high potential for extensive colonization because it recognizes the host plant and has a higher tolerance to environmental conditions, such as high stress (Sadhana 2014; Quiroga et al. 2017). Based on these characteristics, it can be speculated that indigenous endomycorrhizae isolated from salak roots has great potential to be developed as biofertilizer because it adapts to host plants to be fertilized (Sasvari 2012; Sadhana 2014; Hohmann \& Messmer 2017).

\section{CONCLUSIONS}

The current prototype of indigenous endomycorrhizae biofertilizer increased the yield and quality of the fruits in organic salak. Also, the nutrient level, the relative water content of the leaves, and the photosynthesis process were improved.

\section{ACKNOWLEDGEMENTS}

Our gratitude goes to Universitas Udayana for financial support through Udayana Invention Grants in 2019. The authors also thank the Directorate General of Higher Education, Ministry of Research, Technology and Higher Education for financial support through the Higher Education Applied Grants 2018 .

\section{REFERENCES}

Abbasi, Hisamuddin, Akhtar H, Sharf R. 2015. Vesicular Arbuscular Mycorrhizal (VAM) Fungi: a tool for sustainable agriculture. Amer J Plant Nutr Fert Techno 5(2):40-9.

Baslam M, Garmendia I, Goicoechea N. 2011. Arbuscular Mycorrhizal Fungi (AMF) improved growth and nutritional quality of greenhousegrown lettuce. J Agr Food Chem 59(10):5504-15.

Beltrano J, Ruscitti M, Arango MC, Ronco M. 2013. Effects of arbuscular mycorrhiza inoculation on plant growth, biological and physiological parameters and mineral nutrition in pepper grown under different salinity and P levels. J Soil Sci Plant Nutr 13 (1):123-41.

Bitterlich M, Rouphael Y, Graefe J, Franken P. 2018. Arbuscular mycorrhizas: a promising component of plant production systems provided favorable conditions for their growth. Front Plant Sci 29:1329. doi: $10.3389 /$ fpls.2018.01329

Brundrett MC. 2017. Global diversity and importance of mycorrhizal and nonmycorrhizal plants. In Tedersoo L, editor. Biogeography of Mycorrhizal Symbiosis. Ecological Studies Vol. 230. Switzerland: Springer International Publishing. p. 533-56. https://doi.org/10.1007/978-3-31956363-3-21 
Brundrett MC, Tedersoo L. 2018. Evolutionary history of mycorrhizal symbioses and global host plant diversity. New Phytot 220:1108-15.

Fediala W, Mosa AE, Paszt LS, Frac M, Trzcinski P, Treder W, Klamkowski K. 2018. The role of biofertilizers in improving vegetative growth, yield and fruit quality of apple. Hort Sci 45(4):173-80. https://doi: 10.17221/101/2017-HORTSCI

Giovannetti M, Mosse B. 1980. An evaluation of techniques for measuring vesicular arbuscular mycorrhizal infection in roots. New Phytol. 84(3):489-500. https://doi:10.1111/j.1469-8137. 1980.tb04556.x.

Hernadi P, Sasvari Z, Albrechtova J, Vosatka M, Posta K. 2012. Arbuscular mycorrhizal inoculants increase yield of spice pepper and affects indigenous fungal community in the field. Hort Sci 47(5):603-6.

Hohmann P, Messmer MM. 2017. Breeding for mycorrhizal symbiosis: focus on disease resistance. Euphytica 213(113):1-11. doi: 10.1007/s10681$017-1900-\mathrm{x}$

INVAM (International Culture Collection of Vesicular Arbuscular Mycorrhizal Fungi). 2017. Species descriptions from reference cultures. http:// fungi.invam.wvu.edu/the-fungi/speciesdescriptions.html. (26 June 2017).

Jansa J, Smith AF, Smith SE. 2016. Are there benefits of simultaneous root colonization by different arbuscular mycorrhizal fungi?. New Phytol 177:779-89.

Jha S, Kumar KN. 2011. Potential of mycorrhizal fungi in ecosystem: a review. Inter J Res Bot 1(1):1-7.

Juliadewi KAC, Rai IN, Kartini NL. 2014. Aplikasi dosis jamur endomikoriza untuk meningkatkan produksi buah salak Gula Pasir [Application of endomycorrhizal dosage for increasing production of salak cv. Gula Pasir]. Plumula 4(3):19-25.

Kavitha T, Nelson R. 2013. Diversity of Arbuskular Mycorrhizal Fungi (AMF) in the rhizophere of Heliantbus annuus L. Amer-Eurasian J Agric \& Environ Sci 13(7):982-7.

Kehri HK, Akhtar O, Zoomi I, Pandey D. 2018. Arbuscular Mycorrhizal Fungi: Taxonomy and its systematics. Inter J Life Sci Res 6(4):58-71.

Kim SJ, Eo J, Lee E, Park H, Eom A. 2017. Effects of Arbuscular Mycorrhizal Fungi and soil conditions on crop plant growth. Mycobiology 45(1):20-4.

Kruger M. 2011. Molecular phylogeny, taxonomy and evolution of arbuscular mycorrhizal fungi. DNAbased characterization and identification [Dissertation]. Kumulative Dissertation der Fakultat fur Biologie an der Ludwig-MaximiliansUniversitat Munchen Morgantown, West Virginia Agriculture and Foresty Experimental Station.
Mathimaran N, Sharma MP, Raju MB, Bagyaraj DJ. 2017. Mycosphere essay 17 arbuscular mycorrhizal symbiosis and drought tolerance in crop plants. Mycosphere8(3):361-76.doi: 10.5943/mycosphere/ $8 / 3 / 2$.

Mo Y, Wang Y, Yang R, Zheng J, Liu C, Li H, Ma J, Zhang Y, C. Wei, Zhang X. 2016. Regulation of plant growth, photosynthesis, antioxidation and osmosis by an Arbuscular Mycorrhizal Fungi in watermelon seedlings under well-watered and drought conditions. Front Plant Sci 7:644. doi: 10.3389 /fpls.2016.00644

Nepolean P, Jayanthi R, Pallavi RW, Balamurugan A, Kuberan T, Beulah T, Premkumar R. 2012. Role of biofertilizers in increasing tea productivity. Asian Pac J Trop Biomed 13(2):1443-5.

Nikhat N. 2014. Potential of arbuscular mycorrhizal (AM) fungi in reclamation of waste lands. Life Sci 2(3):48-50.

Ningsih DR, Kramadibrata K, Gunawan AW. 2013. Arbuscular Mycorrhizal Fungi associated with bisbul (Diospyros blancoi). BIOTROPIA 20(2):11221. doi: $10.11598 /$ btb.2013.20.2.2.

Nurhandayani R, Linda R, Khotimah S. 2013. Inventarisasi jamur mikoriza vesikular arbuskular dari rhizosfer tanah gambut tanaman nanas (Ananas comosus L. Merr) [Inventory of arbuscular vesicular mycorrhizal fungus from the peat rhizosphere of the pineapple (Ananas comosus L. Merr) plant]. J Protobiont 2 (3):146-51.

Olagunju EO, Owolabi KT, Alaje DO. 2014. Effect of mycorrhiza on plant growth. J Environ Sci Toxicol Food Technol 8(1):83-5.

Proborini MW, Sudana M, Suarna W, Ristiati P. 2013. Indigenous vesicular arbuscular mycorrhizal (vam) fungi in cashew nut (Anacardium occidentale L.) plantation of north east Bali Island-Indonesia. J Biol Agric Healthcare 3(3):114-21.

Quiroga G, Erice G, Aroca R, Chaumont F, Ruiz-Lozano J.M. 2017. Enhanced drought stress tolerance by the arbuscular mycorrhizal symbiosis in a droughtsensitive maize cultivar is related to a broader and differential regulation of host plant aquaporins than in a drought-tolerant cultivar. Front Plant Sci 8:1056. doi: $10.3389 /$ fpls.2017.01056

Rai IN, Semarajaya CGA, Wiraatmaja W. 2010. A Study on the flowering phenophysiology of Gula Pasir snake fruit to prevent failure of fruit-set. J Hort 20(3):216-22.

Rai IN, Wiraatmaja IW, Semarajaya CGA, Alit Astiari NK. 2014. Application of drip irrigation technology for producing fruit of salak 'Gula Pasir' (Salacca Zalacca var. Gula Pasir) off-season on dry land. J Degrade Min Land Manage 2(1):219-22.

Rai IN, Suada K, Praborini M, Wiraatmaja IW. 2018. Spore propagation of indigenous endomychorrizae from several rooting areas of snake fruit on 
different soil water content. Inter J Biosci Biotech 5(2):155-67.

Rai IN, Suada IK, Proborini MW, Wiraatmaja IW, Semenov M, Krasnov G. 2019a. Indigenous endomycorrhizal fungi at salak (Salacca zalacca) plantations in Bali, Indonesia and their colonization of the roots. Biodiversitas 20(8):24106. doi: $10.13057 /$ biodiv/d200840

Rai IN, Suada IK, Wiraatmaja IW. 2019b. Effectiveness of indigenous endomycorrhizal biofertilizer prototype on salak (Salacca zalacca). Paper presented at the $2^{\text {nd }}$ International Conference on Science, Technology and Humanities (ICoSTH 2019). The Patra Bali Resort \& Villas Bali, 14-15 November 2019.

Sadhana, B. 2014. Arbuscular mycorrhizal fungi (AMF) as a biofertilizer: a review. Int J Cur Microbiol App Sci 3(4):384-400.

Sarah S, Ibrar M. 2016. Effects of arbuscular mycorrhizal fungi on spores density and root colonization of four hybrids of sunflower (Heliantbus annuus L.) at different rock phosphate levels. Sarhad J Agric 32(4):258-66.

Sasvari Z, Magurno1 F, Galanics D, Nhu Hang TT, Hong Ha TT, Luyen ND, Huong LM, Posta K. 2012. Isolation and identification of Arbuscular
Mycorrhizal Fungi from agricultural fields of vietnam. Amer J Plant Sci 3:1796-801.

Schubler A, Schwarzott D, Walker C. 2001. A new fungal phylum, the glomeromycota: phylogeny and evolution. Trop Eco 44(2):207-15.

Soka G, Ritchie M. 2016. Contributions of AM fungi and soil organic matter to plant productivity in tropical savanna soils under different land uses. Rhizosphere 4(1):1-8.

Suamba IW, Wirawan IGP, Adiartayasa W. 2014. isolasi dan identifikasi Fungi Mikoriza Arbuskular (FMA) secara mikroskopis pada rizosfer tanaman jeruk (Citrus sp.) di Desa Kerta, Kecamatan Payangan, Kabupaten Gianyar [Isolation and identification of arbuscular mycorrhizal fungi microscopically in citrus plant rhizosphere (Citrus sp.) in Kerta Village, Payangan District, Gianyar Regency. E-J Agro Trop 3(4):201-8.

Tahat MM, Sijam K. 2012. Mycorrhizal fungi and abiotic environmental conditions relationship. Res J Environ Sci 25:431-40. http://dx.doi.org/ 10.3923./rjes.2012.

Tanwar A, Aggarwal A, Kadian N, Gupta A. 2013. Arbuscular mycorrhizal inoculation and super phosphate application influence plant growth and yield of capsicum annuum. J Soil Sci Plant Nutr 13(1):55-66. 